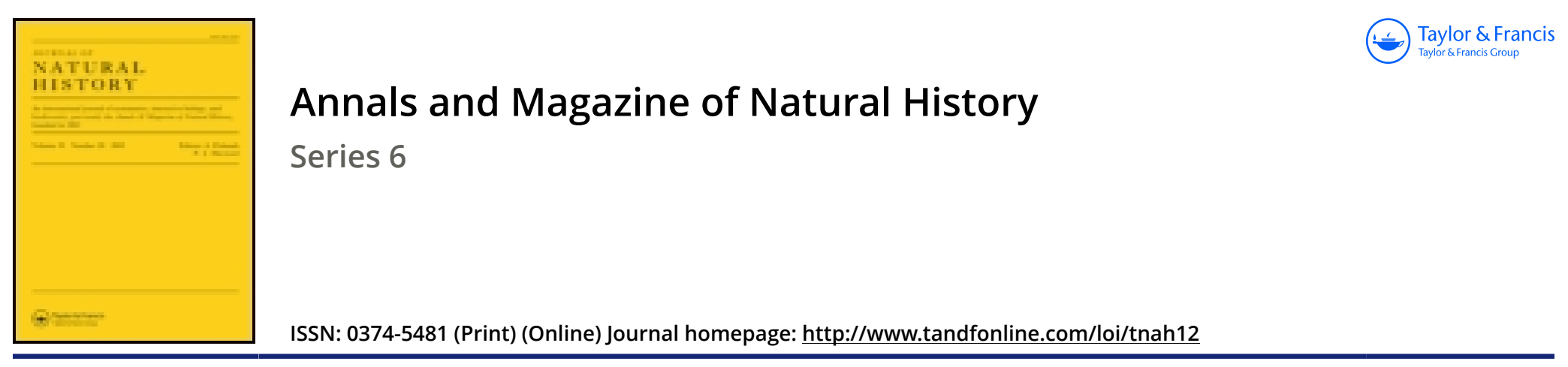

\title{
Results of recent investigations upon the organization of the Nebaliæ and the systematic position of the Leptostraca
}

\author{
Prof. C. Claus
}

To cite this article: Prof. C. Claus (1889) Results of recent investigations upon the organization of the Nebaliæ and the systematic position of the Leptostraca, Annals and Magazine of Natural History, 3:17, 441-443, DOI: 10.1080/00222938909460366

To link to this article: http://dx.doi.org/10.1080/00222938909460366

曲 Published online: 09 Oct 2009.

Submit your article to this journal $\pi$

Џlll Article views: 1

Q View related articles $\sqsubset$ 


\section{MISCELLANEOUS.}

Results of recent Investigations upon the Organization of the Nebaliæ and the Systematic Position of the Leptostraca. By Prof. C. Cxaus.

Anong the Nebalice belonging to the same species we have to distinguish the following forms: (a) sexually mature males, recognizable by the slender, elongated form of the body, the long furcal joints, tufted flagella on the anterior antennæ, and much elongated flagella on the second pair of antennæ; $(b)$ pregnant females, with fans of setre on the terminal joints of each thoracic limb ; (c) sexually mature females and younger females of different sizes, with a coating of short setæe upon the terminal joints of the thoracic limbs; $(d)$ young males of different sizes, recognizable by the shortly annulated flagellar joints of the second antennæ; and (e) larve with three-jointed antennal flagella and the fourth pair of pleopoda still simple.

The northern form, doscribed as $N$. bipes, O. Fabr., is a variety, distinguished by the greater dimensions of its body and the richer articulations of its antennal flagella, of the Adriatic, Mediterranean, and Atlantic Nebalice, to which the Nebalice of the east coast of North America also belong. The Nebalice of the coasts of Chili and Japan (as also the New-Zealaud species described as N. lomitcornis) present such small and unimportant peculiaritios that they may more properly be regarded as varieties of tho same species than as distinct species.

The so-called rostral plate represents a third piece of the carapace, movalily separated as a cephalic flap, which covers two rostral processes of the head, and is so connected with these that, when the head is raised, tho eephalic flap of the carapace is lifted at the same time.

The last two segments of the abdomen, together with the Branchipodiform furea, represent the telson of the Malacostraca, with which they also have in common the ventral position of the anal fissure (on the terminal segment).

The complex structure of the cerebrum, which far exceeds that of the Phyllopod cerebrum, like the intimate structure of the eyeganglion, indicates affinity to the Malacostraca. The middle-brain, with the centres of the olfactory nerves, agrees in the presence of the so-ealled "glomeruli olfactorii "with the "lobi olfactorii" of the Isopoda and Podophthalma. The hind-brain (ganglion of the second pair of antenne) lies on the cesophageal commissure, and possesses a slight subosophageal transverse commissure, which is separated from the commissure of the mandibular ganglion. The mandibular and maxillary ganglia are well separated (as in Apseudes and Spheroma), as are also the eight ganglia of the thoracic segments. In the embryo and larva behind the six abdominal ganglia a seventb ganglion is recognizable; this afterwards becomes retrograde and disappears. 
On the mesial side of the pedunculated eye there is, beneath two tubercles, a special sense-organ of unknown function (frontal organ?). The minute structure of the facetted eye and its ganglion comes nearest to that of the Mysidæ.

The terminal section of the buccal intestine is, as in the Malacostraca, armed with a complex apparatus of chitin-structures, converting it into a gizzard; this apparatus consists of two cardiac jaws, a band of setw on the right side, two pairs of pyloric plates beset with setxe, and a funnel-groove extending far into the intestine. The liver consists of two anterior sacs projecting into the head, and of three pairs of tubular sacs extending backwards as far as the last abdominal segment. The middle intestine and posterior hepatic sacs are imbedded in a perivisceral mass of connective tissue, which also surrounds the sexual glands, the cells of which are filled with fat-globules, and are of great importance in the regulation of the nourishment at the time of the cessation of feeding. Preguant females and sexually mature males gradually use up the nutriment deposited in this tissue, so that, finally, after the disappearance of the fatglobules, the perienterie cell-cord completely shrivels up, while the blood-spaces of the body-carity appear enlarged in the same proportion. At the end of the middle intestines opens an unpaired cæcum situated above the rectum, the cell-covering of which is continued far forward on the dorsal wall of the intestine.

Besides the antennal gland a small shell-gland, reduced almost completely to the terminal saccule, is present, in which, as in the terminal sac of the former, carmine-granules accumulate, after feeding with carmine. The missing looped ducts are replaced by eight pairs of pedal glands, which are coloned blue after feeding with indigo-carmine.

The heart extends from the maxillar region through the whole middle-body into the fourth segment of the abdomen, and is perforated by seven pairs of ostia, the fourth, fifth, and sixth of which are small fissures placed on the dorsal surface, while the rest pertain to the right and left lateral surfaces. Besides an anterior and a posterior anrta there are ramified arteries in the abdomen and in both pairs of antennæ.

The efferent ducts of the sexual glands resemble those of the Malacostraca both in position and in their mode of opening. The females carry their eggs and young, like the Arthrostraca and other Podophthalma, on the pectoral surface of the middle-body betwcen the lamellar pairs of limbs and their fans of setæ, as in a basket through which the water flows, and they also harbour the batehed and moulting larvæ for a considerable time in this brood-chamber.

The Leptostraca are to be regarded as the first main division of the Malacostraca.

The fossil Ceratiocaridæ, together with allied palæozoic genera of Crustacea, judging from their possession of morable cephalic flaps, belong to the same developmental series as the Leptostraca, but cannot be united in tho same order with them, as the organization 
and the structure of the parts of the mouth and the limbs, as well as the relative number of the segments, may bare been very different (leaving quite out of consideration the very different form of the extremity of the abdomen).-Anzeiger (l.k. Aliad. Wiss. Wien, December 13, 1888 , p. 247 .

\section{On the Formation of the Antherozoids of the Characex.}

By M. Leon Guignard.

The antherozoids of the Characeæ, Muscineæ, and vascular Cryptogamia have the form of a spiral filament furnished with cilia, originating by special metamorphosis of the contents of the mothercell. In its formation the nuclens of the mother-cell plays an essential part; it does not dissolve, as was at first supposed, but concurs directly in furnishing the body of the antherozoid, while the cilia proceed solely from the protoplasm.

But is the body of the antherozoid solely derived from the nucleus or both from the nucleus and the protoplasm? If it is furnished by the nucleus alone, nourished by all the portion of the protoplasm which is not employed in the formation of the cilia, how is this metamorphosis effected? If, on the contrary, the protoplasm furnishes a portion of the body, does the differentiation of the spiral filament commence at the expense of the protoplasm and not of the nucleus, as has recently been asserted? Lastly, how and at what moment do the cilia originate? These are so many general questions upon which the extant data are insufficient or contradictory.

By a comparative study of the various groups of Cryptogamia the author has been enabled to clear up the doubtful points, and has arrived at results the agreement and generality of which render them interesting. In the present note he deals with the Characeæ.

In these plants the autheridian filaments are formed of superposed discoidal joints, which represent the mother-cells of the antherozoids. To ascertain the parts played by the nucleus and protoplasm in the formation of the latter these cells must be dissociated and their contents carefully isolated after fixation and hardening. By varions methods of double coloration the substance of the nucleus may be very clearly distinguished from that of the protoplasm, and all stages of the development may be followed step by step.

At the moment when the antherozoid is about to originate the nucleus moves to the side of the mother-cell, so that its outer surface is only covcred by a very thin layer of hyaline protoplasm. On this outer surface a small thickening-band afterwards appears, more refractive than the rest of the nucleus which produces it by a special metamorphosis of its substance. This band forms part of the nucleus without producing a salient crest on its outer surface, and following its contour it resembles a short and rery open crescent. 